\title{
PERAN PEMBERIAN PSYCHOLOGICAL EMPOWERMENT TERHADAP KEPERCAYAAN ATASAN PADA BAWAHAN: LITERATURE REVIEW
}

\author{
Fitri Nafiatus Saidah ${ }^{1}$, Abdul Muhid ${ }^{2}$ \\ fitrinafiatus29@gmail.com, abdulmuhid@uinsby.ac.id \\ UIN Sunan Ampel Surabaya
}

\begin{abstract}
ABSTRAK
Alasan yang memicu saya menulis paragraph pada literature review ini untuk membahas tentang bagaimana pemberian pemberdayaan psikologi (Psychological Emporwerment) kepada kepercayaan pemimpin terhadap bawahan. Untuk bisa maju, sebuah perusahaan membutuhkan tenaga kerja yg berkualitas di dalamnya. Karyawan didorong untuk menggunakan kapasitas yg dimilikinya agar dapat bekerja dengan optimal. Dengan demikian, apabila tenaga kerja memiliki kualitas yg baik, maka perusahaan semakin mudah untuk mencapai tujuannya. Dalam penelitian ini, proses perolehan data menggunakan metode kualitatif dengan pendekatan literatur review dengan menggunakan daftar Pustaka baik dari jurnal, artikel atau buku. Gagasan utama atau permasalahan yang akan bahas dalam menulis paragraph pada literature review ini adalah pemberian psychological empowerment terhadap kepercayaan atasan pada bawahan. Psychological empowerment, Kepercayaan, serta posisi atasan dan bawahan. Yang dimana fungsi Psychological empowermen atau Pemberdayaan psikologis diartikan sebagai motivasi intrinsik yg di golongkan menjadi 4 bagian kognisi, yakni meaning (bermakna), competence (kompetensi), self determination (penentuan nasib sendiri), dan impact (dampak)terhadap timbulnya suatu kepercayaan antara pegawai maupun atasan. Karena kepercayaan merupakan elemen yang mendasar dalam kepemimpinan terutama dalam organisasi / perusahaan, maka ada hubungan yg kuat antara kepemimpinan dan kepercayaan. Salah satu faktor yg mempengaruhi kinerja karyawan adalah kepercayaan. Jika karyawan memiliki rasa kepercayaan kepada pimpinannya, maka budaya organisasi dapat diwujudkan secara optimal oleh pimpinan perusahaan. Perilaku pemimpin seperti kognisi dan toleransi yg dimilikinya salah satu kunci yang dapat menunjukkan bahwa kepemimpinan yang diterapkan di perusahaan itu menjadi berjalan dengan benar. Jika pemimpin perusahaan percaya terhadap bawahannya, maka ia akan merasa termotivasi untuk melaksanakan pekerjaan dengan lebih baik. Kepemimpinan efektif dapat dibangun dengan komunikasi dan koordinasi yang efektif dengan semua bawahan.

Kata Kunci: Psychological Emporwerment, Kepercayaan, Atasan pada bawahan
\end{abstract}


Fitri Nafiatus Saidah, Peran Pemberian Psyc

\section{ABSTRACT}

The reason that triggered me to write a paragraph in this literature review is to discuss how to provide psychological empowerment (Psychological Emporwerment) to the leader's trust in subordinates. To be able to progress, a company needs a qualified workforce in it. Employees are encouraged to use their capacity in order to work optimally. Thus, if the workforce has good quality, it will be easier for the company to achieve its goals. In this study, the data acquisition process uses a qualitative method with a literature review approach using a bibliography from journals, articles or books. The main idea or problem that will be discussed in writing a paragraph in this literature review is the provision of psychological empowerment to superiors' trust in subordinates. Psychological empowerment, trust, and the position of superiors and subordinates. Which is where the function of Psychological empowerment is defined as intrinsic motivation which is classified into 4 parts of cognition, namely meaning (meaningful), competence (competence), selfdetermination (self-determination), and impact (impact) on the emergence of a trust between employees. as well as superiors. Because trust is a fundamental element in leadership, especially in organizations/ companies, there is a strong relationship between leadership and trust. One of the factors that affect employee performance is trust. If employees have a sense of trust in their leaders, then organizational culture can be realized optimally by company leaders. Leader behavior such as cognition and tolerance is one of the keys that can show that the leadership applied in the company is running properly. If the company leader believes in his subordinates, then he will feel motivated to do a better job. Effective leadership can be built with effective communication and coordination with all subordinates.

Keywords: Psychological Emporwerment, Trust, Superiors to subordinates

\section{PENDAHULUAN}

Penentu keberhasilan dan kemajuan suatu perusahaan salah satunya berada di tangan pegawai. Pegawai inilah yang nantinya menjadi penerus untuk melakukan suatu perubahan,pada kenyataannya hinggasekarang masih banyak para pegawai yang hidup dan beraktivitas dalam bekerja kurang semangat dan percaya diri (Iqbal \& Kurniasih dkk, 2016). Fenomena pentingnya pemberian psychological empowermen ini menjadi suatu problematika yang sangat serius dan memerlukan perhatian serius dari berbagai kalangan terutama atasan(Munadharoh, 2013). Menurut Munadharoh, (2013) fenomena ini telah menjadi suatu fakta global didunia kerja. Tingginya tingkat persaingan menyebabkan perusahaan membutuhkan pegawai yang istimewah,ahli, dan memiliki percaya diri yang tinggi dalam keterlibatan pada pekerjaan.

Menurut Iqbal \& Kurniasih dkk, (2016) kepuasaan dalam bekerja ialah menggambarkan perasaan seseorang pegawai dalam menjalani pekerjaannya. Kepuasan 
dalam bekerja adalah masalah pribadi, berdasarkan nilai yang berlaku padanya, setiap individu pegawai tingkat kepuasan yang dimiliki berbeda-beda. Kepuasan dalam pekerjaan sulit untuk didefinisikan, karena kepuasan bukanlah suatu keadaan emosional etos kerja permanen, tetapi dapat diubah oleh kekuatan dari dalam diri pegawai atau luar lingkungan kerja (Sukrajap, (2016). Kepuasan karyawan yang tinggi akan berdampak positif bagi kemajuan perusahaan, sehingga begitu penting untuk perusahaan yang sedang berupaya meningkatkan kepuasan pegawai dalam menyelesaikan pekerjaan. Salah satu figurepemimpin terkemuka yang menjadi teladan bagi bawahannya,maka karenanya kepemimpinan merupakan salah satu fakto begitu penting dalam pengembangan diri bawahan, bawahan didorong untuk berpikir serta bertindak inovatif dan juga produktif dalam menyelesaikan tugas ataupun masalah guna mencapai tujuan organisasi (Subagio, 2015).

Bentuk kepemimpinan yang aktif, otentik, transparan dan beretika (real leadership) merupakan solusi alternatif bagi organisasi untuk menghadapi berbagai tantangan (Hardianto, 2018). Menurut Munadharoh, (2013) Minat yang berkembang untuk membahas kepemimpinan sejati dalam dunia akademis dan praktik semakin memperkuat hal ini.Kepemimpinan sejati bias ditunjukkan melaluikesadaran diri, percaya diri, dan perilaku pemimpin harus jelas. Studi empiris yang telah ada menunjukkan tentang kemampuan pemimpin sejati menumbuhkan berbagai efek begitu positif pada etos,tingkah laku, dan kinerja pegawai perusahaan, yakni perilaku kewarganegaraan organisasi, otorisasi, kinerja, kepuasan kerja, dan komitmen organisasi (Hardianto, 2018). Hal ini tentunya membutuhkan pemaparan lebih lanjut tentang implementasi kepemimpinan yang sebenarnya memberikan daan bisa memberikan manfaat positif bagi organisasi. Dalam artikel ini peneliti memiliki tujuan untuk mempertahankan dan melanjutkan momentum pertumbuhan penelitian kepemimpinan nyata, dengan memperdalam pemahaman tentang cara-cara di mana pemimpin sejati memiliki konsekuensi positif (Hariri, 2011). Menurut (Sukrajap, 2016) menjelaskan pemimpin autentik yang selalu memberikan empowerment kepada para karyawan dan berpengaruh pada berbagai konsekuensi yang diungkapkan bahwa leader-member exchange, and than personal identification, anda than social identifycation, and than trust in manager follower empowerment, and than identification with supervisor yang dimana membahas antara hubungan sertaa manfaat kepemimpinan autentik serta berbagai perilaku bawahan. 
Kepercayaan atasan dan bawahan mempengaruhi kepuasan pegawai dalam bekerja, dipengaruhi factor model kepemimpinan ini dapat memotivasi terhadapkinerja pegawai (Hariri, 2011). Ketika pimpinan perusahaan melibatkan karyawan dalam pengambilan keputusan, Kepercayaan diri pegawai dalambekerja akan meningkat dengan meningkatnya semangat kerja karyawan. Penerapan model pemimpin jiwa transformasional akan menjadikan tingkat loyalitas dan menghormati atasannya lebih tinggi. Maka dari itu dapat menginspirasi mereka agar dapat melakukan yang terbaik (Iqbal \& Kurniasih dkk, 2016). Komunikasi hubungan yang berjalan baik antara atasan dan anggota dapat meningkatkan etos kinerja karyawan, serta pegawai akan merasakan dianggap jadi bagian diperusahaan. Kepuasan dalambekerja diteliti banyak ahli, salah satunya (Sukrajap, 2016) dan (iqbal \& Kurniasih dkk, 2016) Hal ini menunjukkan bahwa salah satu model kepemimpinan yang transformasional memberikan dampak yang signifikan terhadap kepuasan kerja pegawai perusahaan dengan melakukan konsep pemberdayaan karyawan. Kepuasan dalam bekerja yang masih berkaitan dengan keinginan karyawan untukdapat mengembangkan keterampilan dalam bekerja. Yang mengakibatkan mereka merasa diperdulikan kebahagiaannya oleh perusahaan. Perusahaan yang dapat memberdayakan karyawan melalui perilaku pemimpin yang tepat bias meningkatkan kepuasan kerja karyawan, loyalitas karyawan tinggi, dan kemauan berinovasi dalam bekerja. Salah satu karakteristik pemimpin transformasional harus mampu memberdayakan karyawan dengan baik. Melalui pemberdayaan akan memberikan motivasi kepada karyawan untuk lebih berpartisipasi dalam pengambilan keputusan internal perusahaan, sehingga meningkatkan rasa tanggung jawab dan meningkatkan kinerja, yang juga mempengaruhi karyawan dan meningkatkan kepuasan kerja karyawan (Unika Prihatsanti, 2017). Oleh karena itu pemberdayaan pada karyawan yang terjadi didalam perusahaan pimpinan akan memberikan peluang bagi karyawan untuk mengembangkan potensi yang dimilikinya. Perlakuan pemimpin dan pemberdayaan terhadap pegawai adalah salah satu hal penting serta bisa berdampak positif bagi kinerja karyawan (Sukrajap, 2016).

Begitu besar kepercayan atasan yang diberikan terhadap karyawan, karena hal itu akan berdampak baik bagi perkembangan perusahaan (Hariri, 2011). Perusahaan berusaha untuk melakukan upaya peningkatan kepuasan kerjakaryawan. Empowermen dapat suatu motivasi positif untuk melakukan pemberdayaan terhadap karyawan, oleh karena itu pemberdayaan karyawan adalah sesuatu hal yang sangat penting dalam aspek lingkungan pekerjaan yang berupa pemberian tanggungjawab kepada karyawan dalam 
pengambilan keputusan yang berkaitan dengan pengembangan produk sehingga dapat memberikan keunggulan kompetitif perusahaan secara berkelanjutan (Bina Muwadah, 2017). Pemberdayaan merupakan keleluasan kepada seseorang untuk bertindak sekaligus bertanggungjawab atas tindakannya sesuai dengan tugasnya, Pemberdayaan karyawan merupakan suatu proses untuk menjadikan individu menjadi lebih berdaya dalam menyelesaikan suatu permasalahan yang berkaitandenganpekerjaan (Sukrajap, 2016)

Empowermen salah satu pwer yang dapat menjadi motivasi positif untuk melakukan pemberdayaan terhadap karyawan. Oleh karena itu pemberdayaan karyawan sesuatu yang sangat penting dalam lingkungan pekerjaan, yang berupa pemberian tanggung jawab kepada karyawan dalam pengambilan keputusan yang berkaitan dengan pengembangan produk. Sehingga bisa memberikan keunggulan kompetitif bagi perusahaan secara berkelanjutan (Bina Muwadah, 2017). Pemberdayaan merupakan keleluasan kepada seseorang agar bertindak sekaligus bertanggung jawab atas pekerjaanya, Pemberdayaan karyawan merupakan suatu proses yang dapat menjadikan individu menjadi lebih berdaya dalam menyelesaikan suatu permasalahan yang berkaitan dengan pekerjaan (Sukrajap, 2016). Pemberdayaan merupakan salah satu mekanisme yang digunakan untuk mempromosikan pengembangan karyawan dalam rencana jangka panjang organisasi. Berbagai riset empiris yang telah dilakukan sebelumnya menunjukkan bagaimana kemampuan pemimpin autentik memberikan berbagai pengaruh positif terhadap sikap, perilaku, maupun kinerja dari bawahan seperti organizational citizenship behavior, empowerment, kinerja, kepuasan kerja), serta komitmen organisasional Hal ini tentu saja membutuhkan berbagai penjelasan lebih lanjut kaitannya dengan bagaimana mekanisme kepemimpinan autentik dapat memberikan berbagai manfaat positif bagi organisasi (Munadharoh, 2013).

Terdapat penelitian terdahulu yang menjadi ilmu pengetahuan evaluasi perihal ini, yakni lebih banyak berkaitan tentang pengaruh enrichment dan empowerment kepada kompetensi dalam meningkatkan performan kinerja karyawan (Bina Muwadah, 2017). Oleh karena itulah kepemimpinan itu sangat berpengaruh terhadap pemberdayaan pada anggota agar dapat meningkatkan manajemen diri dan keterampilan kepemimpinaan. Oleh karena itu bisa mengembangkan kinerja karyawan (Munadharoh, 2013).

Pada artikel literatur review ini dilakukan serta disusun dengan maksud dan tujuan untuk mengevaluasi proses penerapan dan mengetahui pengaruh pemberian empowermen oleh atasan yang diberikan kepada bawahan pada performansi kerja. Dalam penelitian ini 
akan membahas performansi kerja yang menyeluruh dengan menggabungkan konsep empowermen, kemampuan berprestasi, kesediaan berprestasi (motivasi), serta kondisi kerja. Diharapkan dengan mengetahui keterkaitan antara setiap aspek, maka dapat dilakukan pengelolaan sistem insentif yang lebih baik lagi sehingga dapat memberikan kepuasan pada pekerja dan meningkatkan performansi organisasi secara keseluruhan. Selain itu, dari penelitian kali ini diharapkan juga dapat diperoleh model empowermen dan performansi, sehingga dapat mengatasi permasalahan yang ada dan dapat diterapkan pada organsisasi lain yang sejenis.

\section{METODE}

Metode yang digunakan dalam penulisan ini berjenis literature review. Literature review adalah proses meletakan, mendapatkan, membaca, dan mengevaluasi. Dalam metode kali ini menggunakan menggunakan jurnal atau artiker dari berbagai sumber sebagai pusat acuan bahan referensi. Penulis juga melakukan studi literarut review mengenai Pemberdayaan Psikologi Terhadap Kepercayaan Atasan Pada Bawahan, pada jurnal atau artikel yang dicari sebagai perlengkap tulisan literatur riview ini. Darimana penulis mendapatkan data tersebut? Google scholar dan sciencedirect.

\section{PEMBAHASAN}

Ada beberapa point dalam penyusunan paragraf penelitian literature review dengan permasalahan yang diangkat Peran Pemberian Psychological Empowerment Terhadap Kepercayaan Atasan Pada Bawahan. Pertama,Kepercayaan Karyawan. Kedua, Pemberdayaan Psikologi.Ketiga, Peran Pemberdayaan Psikologis Terhadap Kepercayaan Karyawan. Dengan penjelasan sebagai berikut:

\section{Kepercayaan Karyawan}

Bahwa Kepercayaan didefinisikan sebagai keyakinan karyawan bahwa rekanrekannya akan melakukan hal-hal positif untuknya(Srimardika, 2016). Keyakinan ini tidak muncul begitu saja, tetapi melalui proses interaksi dan pengamatan rekan kerja dan karyawan.Srimardika, (2016)menjelaskan bahwa kepercayaan mencakup unsur-unsur, yakni karyawan yang akan berada dalam situasi di mana memilih untuk mempercayai rekan dan team kerja mungkin memiliki konsekuensi yang akan menguntungkan atau malah merugikan. Maka karena itu, karyawan akan menyadari, jika kepercayaan itu berisiko, karyawan menyadari bahwa untung ataupun rugi itu berdasarkan dari pada 
perilaku rekan kerja, dan karyawan pun juga dapat percaya bahwa rekan kerja bisa bertindak seolah-olah hasilnya bermanfaat (Asikin, 2015).

Menurut (Iqbal \& Kurniasih dkk, 2016)Kepercayaan merupakan elemen dasar dari kepemimpinan, sehingga kepemimpinan erat kaitannya dengan timbulnya suatu kepercayaan. Dalam kepemimpinan, timbulnya kepercayaan akan berperan dalam perilaku individu karyawan, jika seorang pemimpin mendapatkan kepercayaan karyawan, ia dapat menciptakan budaya organisasi yang baik. Kepercayaan pada pemimpin berkorelasi positif menunjukan hasil yang begitu positif seperti perilaku terhadap kinerja dan kepuasan, semakin tinggi kepercayaan dan komunikasi oleh pemimpin dan bawahannya, semakin akurat komunikasi serta informasi yang dirasakan, semakin akurat pemahaman terhadap tujuan kinerja, dan akan semakin tinggi kualitas suatu komunikasi. Hubungan yang terjadi antara pemimpin dengan karyawannya serta memiliki rasa menghormati,saling kerjasama,bisa komitmen,sadar akan keterlibatan kerja serta dapat diandalkan akan menjadikan hubungan saling percaya oleh atasan dan bawahan akan terjalin semakin baik (Srimardika, 2016). Kepercayaan adalah salah satu aspek kunci terpenting dan terpenting dalam membangun komitmen dan komitmen. Jadi secara singkat dapat dijelaskan bahwa keyakinan atau trust merupakan faktor penting yang dapat dicapai, yang akan berarti di masa yang akan datang.Menurut Hardianto, (2018)Pada dasarnya, pemberdayaan merupakan perpaduan antara pemberdayaan pemimpin dan lingkungan. Suatu organisasi harus memahami dan mampu mengidentifikasi berbagai faktor yang dapat menjadi dasar kepercayaan sehingga dapat menciptakan, menciptakan, mengatur, memelihara dan memperkuat tingkat hubungan antar pelanggan. Ada pandangan kepercayaan, ketika salah satu pihak memiliki keandalan dan integritas pihak lain tetapi masih memiliki kepercayaan pada pihak yang berpartisipasi dalam pertukaran, maka dapat dikatakan memiliki kepercayaan. (Unika Prihatsanti, 2017).

Ada tiga dimensi kepercayaan: (1) kompetensi, didefinisikan sebagai keterampilan, kemampuan, dan bidang profesional yang memungkinkan penguasa berhasil di bidang tertentu, (2) karakter, menyampaikan perasaan konsistensi antara kata dan perbuatan, penguasa menepati janji, konsisten dengan kata dan perbuatan, Apa yang mereka lakukan, mereka akan melakukan apa. Artinya otoritas memiliki integritas, dan mereka memiliki motif dan niat yang jujur , (3) kebajikan didefinisikan sebagai percaya bahwa otoritas ingin berbuat baik untuk wali, jika otoritas dianggap baik hati, yaitu peduli karyawan, peduli kesejahteraan, dan setia kepada karyawan (Asikin, 2015). 


\section{Pemberdayaan Psikologis}

Apa yang dimaksud Pemberdayaan? pemberdayaan adalah pemberian kekuasaan pengambilan keputusan dalam organisasi tanpa menunggu persetujuan dari pimpinan. Inti dari pemberdayaan adalah kebebasan untuk menyelesaikan tugas-tugas yang berkaitan dengan aktivitas pegawai. Pemberdayaan juga merupakan transfer kekuasaan dari pemberi kerja kepada pekerja. Pengalihan kekuasaan tidak hanya sebagai bentuk pemberian kebebasan bertindak, tetapi juga rasa tanggung jawab dan tanggung jawab yang tinggi terhadap pekerjaan (Sukrajap, 2016). Sedangkan yang dimaksud dengan psikologi pemberdayaan? Pemberdayaan psikologis ialah salah satu struktur berupa motivasi yang berfokus pada kognisi individu yang bisa diberdayakan. Individu yang berwenang harus berkinerja lebih baik daripada individu yang kurang berwenang..Hal ini juga dapat dijelaskan oleh (Sukrajap, 2016) bahwa persepsi pemberdayaan secara langsung berkaitan dengan faktor perilaku, aktivitas, perhatian, inisiatif, dan fleksibilitas, yang dapat meningkatkan kinerja pribadi

Psychological empowerment bisa dipahami sebagai proses pemberdayaan atau juga terhadap keadaan mental, diwujudkan dalam empat subbab kognisi makna (meaning), kemampuan (competence), penentuan nasib sendiri (self determination) dan pengaruh(impact) (Munadharoh, 2013). Secara khusus, makna mengacu pada keyakinan seseorang bahwa pekerjaannya penting, kompetensi mengacu pada efikasi diri, atau keyakinan pada kemampuannya untuk berhasil menyelesaikan tugas, penentuan nasib sendiri mengacu pada perihal keluasaan dalam memilih bagaimana memulai dan melakukan tugas, dan pengaruh mewakili suatu derajat individu dalam pandangan perilaku seseorang berdampak pada hasil kerja. Ini juga memberikan bukti bahwa empat dimensi (makna, kemampuan, penentuan nasib sendiri, dan pengaruh, meskipun berbeda, mencerminkan pengembangan pemberdayaan psikologis secara keseluruhan). Oleh karena itu, pemberdayaan psikologis dipandang sebagai proses untuk meningkatkan inisiasi tugas dan ketekunan karyawan (Bina Muwadah, 2017).

Psychological Empowermentdapat diartikan juga sebagai Anggota percaya bahwa mereka memiliki salah satu kesempatan untuk membantu serta menentukan peran pekerjaan, menyelesaikan tanggungjawab pekerjaan yang berarti, serta dapat mempengaruhi keputusan penting.Pemberdayaan dianggap penting karena pengambilan keputusan yang lebih baik, kualitas yang lebih tinggi, lebih banyak inovasi dan kepuasan kerja yang lebih tinggi (Sukrajap, 2016) 


\section{Peran Pemberdayaan Psikologis Terhadap Kepercayaan Karyawan}

Peran pemberdayaan psikologis terhadap kepercayaan pegawai sangatlah begitu penting. Pegawai yang mempunyai kepercayaan terhadap teman kerja dan pimpinan akan merasa terdorong untuk melaksanakan pekerjaannya dengan lebih baik. Kepemimpinan efektif dapat dibangun dengan komunikasi dan koordinasi yang efektif dengan semua bawahan (Srimardika, 2016). Kepercayaan pegawai terhadap intitusi atau organsasi akan membuat pegawai berkeyakinan dalam diri untuk bekerja dengan lebih baik. Penelitian (Unika Prihatsanti, 2017) menyatakan Hubungan kepercayaan tempat kerja dengan rekan kerja, supervisor dan manajer, organisasi yang tepat dan tidak tepat akan berpengaruh pada motivasi karyawan

Namun, juga dapat dirasa perlunya empowermen leadership yang harus diberikan oleh atasan kepada bawahan agar para pekerja merasa dianggap, dihargai serta terkesan dirinya berharga Empowering leadership. Sebagai tingkah laku dalam hal kekuasaan terhadap bawahan agar dapat meningkatkan power motivasi batin mereka. Misalnya: memimpin yang selalu memberikan hal contoh, membuat keputusan yang selalu mementingkan partisipatif, melatih, memberi informasi, dan peduli (Bina Muwadah, 2017). Dalam kepemimpinan yang didelegasikan, hubungan yang dilakukan berdasarkan kerja sama tim akan melibatkan kepuasan empat kondisi: (1) pendelegasian kepemimpinan terkait dengan berbagi pengetahuan, (2) berbagi ilmu pengetahuan terkait kinerja didalam tim, (3) pendelegasian kepemimpinan terkait dengan kinerja didalam tim, dan (4) ) Ketika berbagi pengetahuan ditambahkan sebagai pengantar model, hubungan antara kepemimpinan yang diberdayakan dan kinerja tim akan melemah (Munadharoh, 2013). Menurut Munadharoh, (2013) . Empowering leadership yang dapat berhubungan secara konsisten melalui proses kerjsama tim yang lebih baik, belajar dan refleksi. (Psikologi pemberdayaan: hubungannya dengan kepuasan kerja dan komitmen emosional).Oleh karena itu, dapat dibuktikan dan disimpulkan bahwa pembinaan yang langsung mengarah pada rasa aman psikologis dalam tim, memungkinkan eksperimen dan pembelajaran. Empowering leadershipItu juga ditemukan terkait dengan tim proses pembelajaran, digunakan untuk berbagi perihal apapun informasi, berkomunikasi secara terbuka, memberikan dan mencari umpan balik secara efektif. Ini juga diharapkan dapat mengarah ke tim yang lebih reflektif, yang pada gilirannya dikaitkan dengan kinerja tim yang lebih baik. Anggota percaya bahwa mereka memiliki kesempatan untuk membantu menentukan peran pekerjaan, menyelesaikan pekerjaan yang berarti, dan mempengaruhi 
keputusan penting. Pemberdayaan dianggap penting karena dapat membawa potensi manfaat, antara lain peningkatan komitmen, pengambilan keputusan dilakukan secara baik, mempertimbangkan peningkatan kualitas,serta inovasi yang lebih banyak, dan peningkatan kepuasan kerja (Bina Muwadah, 2017).

\section{SIMPULAN DAN REKOMENDASI}

Dari hasil pemaparan didalam artikel literature yang ditulis dapat diambil kesimpulan, bahwa :

1. Bahwa Kepercayaan didefinisikan sebagai keyakinan karyawan bahwa rekanrekannya akan melakukan hal-hal positif untuknya. Keyakinan ini tidak muncul begitu saja, tetapi melalui proses interaksi dan pengamatan rekan kerja dan karyawan. kepercayaan mencakup unsur-unsur, yaitu, karyawan berada dalam situasi di mana memilih untuk memercayai rekan kerja mungkin memiliki konsekuensi yang menguntungkan atau merugikan. Oleh karena itu, karyawan menyadari bahwa kepercayaan itu berisiko, karyawan menyadari bahwa untung atau rugi tergantung pada perilaku rekan kerja, dan karyawan percaya bahwa rekan kerja akan bertindak seolah-olah hasilnya bermanfaat.

2. Psychological empowerment didefinisikan sebagai Suatu proses pemberdayaan atau keadaan mental, diwujudkan dalam empat kognisi makna, kemampuan, penentuan nasib sendiri dan pengaruh.Psychological Empowermentdapat diartikan juga sebagai Anggota percaya bahwa mereka memiliki kesempatan untuk membantu menentukan peran pekerjaan, menyelesaikan pekerjaan yang berarti, dan mempengaruhi keputusan penting.Pemberdayaan dianggap penting karena pengambilan keputusan yang lebih baik, kualitas yang lebih tinggi, lebih banyak inovasi dan kepuasan kerja yang lebih tinggi.(Sukrajap, 2016)

3. Peran Pemberdayaan Psikologis Terhadap Kepercayaan Karyawan merupakanbahwa pembinaan mengarah pada rasa aman psikologis dalam tim, memungkinkan eksperimen dan pembelajaran. Empowering leadership Itu juga ditemukan terkait dengan tim proses pembelajaran, digunakan untuk berbagi informasi, berkomunikasi secara terbuka, memberikan dan mencari umpan balik. Ini juga mengarah ke tim yang lebih reflektif, yang pada gilirannya dikaitkan dengan kinerja tim yang lebih baik. Anggota percaya bahwa mereka memiliki kesempatan untuk membantu menentukan peran pekerjaan, menyelesaikan pekerjaan yang berarti, dan mempengaruhi keputusan 
penting. Pemberdayaan dianggap penting karena dapat membawa potensi manfaat, antara lain peningkatan komitmen, pengambilan keputusan yang lebih baik, peningkatan kualitas, inovasi yang lebih banyak, dan peningkatan kepuasan kerja.

\section{DAFTAR PUSTAKA (A.P.A. Style)}

Asikin, I. (2015). Pengaruh Kepercayaan dan Penghargaan Terhadap Komitmen Organisasai Karyawan, Tribun Jakarta Pusat. 2, 12.

Bina Muwadah, R. (2017). Pengaruh Enrichmentdan Emporwerment TERHADAP Kompetensi DalamMeningkatkan Kinerja Karyawan. Jurnal Manajemen.

Hardianto, H. (2018). Pengaruh budaya organisasi, penghargaan dan kepercayaan terhadap motivasi berprestasi pegawai Dinas Pendidikan Pemuda dan Olahraga Kabupaten Rokan Hulu. Jurnal Akuntabilitas Manajemen Pendidikan, 6(2), 193. https://doi.org/10.21831/amp.v6i2.19489

Hariri, R. E. (2011). Pengaruh Perilaku Kepemimpinan Terhadap KinerjaLayanan Akademik Pegawai di Universitas Pendidikan Indonesi. Jurnal Pendidikan, 10(19), 10.

Iqbal, M., \& Kurniasih dkk, A. (2016). Pengaruh Kepercayaan dan Komitmen Organisasi Terhadap Motivasi dan Kepuasan Kerja. Jurnal Pendidikan , 46, 121-134.

Munadharoh, M. (2013). Analisis Emporwering Leadirship dan Psychological Dalam Organisasi. Jurnal Ekonomi Bisnis, 14, 2.

Srimardika, B. M. (2016). Pengaruh Kepercayaan Karyawan (Trust) Terhadap Knowledge Sharing Pada Karyawan Perpustakaan Institut Teknologi Sepuluh Nopember (ITS) Surabaya. Skripsi.

Subagio, M. (2015). Pengaruh Pemberdayaan dan Motivasi Terhadap Kinerja Karyawan Pada PT Ithaca Resources Jakarrta. 18(1), 11.

Sukrajap, M. A. (2016). Pengaruh Kepemimpinan Transformasional Terhadap Kepuasan Kerja dan Komitmen Organisasional Dengan Dimediasi Oleh Pemberdayaan Psikologis. 24.

Unika Prihatsanti, N. R. A. (2017). Hubungan Antara Kepercayaan Terhadap Pemimpin Dengan Keterikatan Kerja Pada Karyawan PT Telkom Witek Semarang. Jurnal Empati, 6, 4. 